\title{
The Rise and Fall of the Indonesian Economy
}

\author{
Joseph J. Stern \\ CID Working Paper No. 100 \\ June 2003
}

(C) Copyright 2003 Joseph J. Stern and the President and Fellows of Harvard College

\section{Working Papers Center for International Development at Harvard University}




\title{
The Rise and Fall of the Indonesian Economy
}

\author{
Joseph J. Stern
}

\begin{abstract}
The Indonesia crisis was particularly severe. What began as an economic crisis quickly evolved in to a political crisis. Most analysts failed to recognize the growing weaknesses of the economy and were caught by surprise. In part Indonesia's economic success over the period 1985 through 1997 and its records on policy reforms had persuaded many that, despite some obvious weaknesses, it would come through the Asian crisis with minimum damage. A closer analysis of the Indonesia's economic history shows that the initial reforms, carefully crafted by a highly respected group of economic technocrats, tackled many of the most serious distortions that held back economic growth. But as these reforms began to pay off in terms of higher growth rates, sharply declining poverty rates, and an increased level of integration in the global economy, the desire for further reforms waned. Over time the beneficiaries of the early reforms allied themselves with the political elites to block further reforms and in effect reduced the power of the technocrats to resist a return to the dirigiste tendencies that had marked much of Indonesia's early development efforts. While the reforms were important, in retrospect they were insufficient to create an institutional infrastructure that could weather a dramatic economic downturn.
\end{abstract}

Keywords: Indonesia, Economic reforms, Poverty alleviation, Corruption, Economic policy reforms, Asian financial crisis.

JEL codes: O11, O24, O53

Joseph Stern is a Lecturer in Public Policy in the John F. Kennedy School of Government, Harvard University and a Faculty Associate at the Center for International Development. He has served as a resident economic advisor to economic ministries in a number of countries, including most recently Indonesia. 


\title{
Draft: For comments only
}

\section{Not for quotation or attribution}

\section{The Rise and Fall of the Indonesian Economy*}

\author{
Joseph J. Stern \\ John F. Kennedy School of Government \\ Harvard University
}

$\underline{\text { Introduction }}$

The 1997 Asian financial crisis affected a number of the so-called "Asian Tigers" but reserved its strongest, and most lasting, impact for Indonesia. That country's economic implosion caught observers and analysts by surprise because few thought that the Indonesian economy was particularly vulnerable to a financial collapse. ${ }^{1}$ Admittedly Indonesia's economic performance did not match that of the early East Asian developers - Singapore, Hong Kong, Taiwan and especially Korea - but its economic achievements, especially beginning in the latter half of the 1980s and through the first half of the 1990s, had earned Indonesia's economic team increasing respect. Indeed during the period from mid-1985, when a number of major policy reforms were put into place, until mid-1997, when the economic crisis took its toll, Indonesia's economic performance suggested that it was well on its way to joining the ranks of the "Asian tigers." Indonesia's real GDP/capita income, shown in Table 1, grew at a rate that matched that of the rapidly growing Asian economies, especially Malaysia and Korea, although admittedly Indonesia's growth began from a lower absolute per capita income level.

It is perhaps not surprising then that many analysts, encouraged by the improvements they observed in Indonesia's economic management and the results achieved in terms of rapid growth, structural change, and poverty alleviation, praised Indonesia as one of Asia's success stories. Consider for example what the 1997 Global Competitiveness

\footnotetext{
* I am deeply indebted to Matthew Feldmann and Iris Hui who provided exceptionally competent, thorough, and unstinting research assistance. Their efforts are only partly reflected in the materials covered here.

${ }^{1}$ Even as late as June 20, 1997, the IMF would write in its staff report for the 1997 Article IV Consultation that " $[\mathrm{t}]$ he limited contagion effects from recent events in Thailand reflect the solid fundamentals of the Indonesian economy." The report went on to say that comparing Indonesia to Thailand, the "[f]actors influencing the continued market confidence in Indonesia was the less pronounced export slowdown, the smaller external account deficit in relation to GDP, greater exchange rate flexibility, and the modest
} 
Report said about Indonesia's performance. The report pointed out that Brazil, China, India and Indonesia. What is referred to as the "Goliath developing countries," had “...taken important strides in economic reform in the past decade, and all except India advanced in ... the competitiveness ranking ..." and indeed the report showed that Indonesia's global competitiveness ranking rose from $30^{\text {th }}$ place in 1995 to $15^{\text {th }}$ in 1996 , placing it immediately behind Japan. ${ }^{2}$

Table 1

Comparative Rates of Growth for Selected Asian Economies: 1985 - 1997.

\begin{tabular}{llrrrrr}
\hline & \multicolumn{2}{c}{ GNP/capita } & & \\
& \multicolumn{2}{c}{$\begin{array}{c}1985 \\
\text { (Constant } 1995 \\
\text { US dollars) }\end{array}$} & & $\begin{array}{c}\text { Rate of Growth } \\
\text { (Per cent } \\
\text { per annum) }\end{array}$ & t-statistic \\
\hline 1 & Indonesia & 567 & 1,093 & 5.8 & 56.24 \\
2 & Korea, Rep. of & 5,075 & 11,864 & 6.9 & 25.69 \\
3 & Malaysia & 2,466 & 4,465 & 5.4 & 31.72 \\
4 & Philippines & 940 & 1,170 & 1.4 & 7.69 \\
5 & Thailand & 1,311 & 2,821 & 7.1 & 22.57 \\
6 & India & 264 & 411 & 3.7 & 21.63 \\
7 & China & 261 & 679 & 8.4 & 24.50 \\
\hline
\end{tabular}

Note: Derived from semi-log regressions of GNP/capita on time.

Source: Data from World Bank, World Development Indicators.

It was also during the 1990s, when Indonesia seemed on a fast development track that its economic policies were held up as an object lesson for other developing countries, most notably for the lagging African economies. ${ }^{3}$ Indonesia, which had put in to place many of the policy prescriptions that closely resembled the "Washington Consensus," was considered an appropriate role model because it had managed to shift from a relatively closed economy with strong protection for nearly all domestic sectors, to a more open economy that was increasingly able to compete in the global market. Not only had this transformation been successful, resulting in a substantial acceleration of economic growth combined with a strong decline in the number of Indonesians counted as poor.

amount of outstanding short-term obligations in relation to total external debt (under 15 percent) and to total official reserves (about one-third)." (p. 8)

${ }^{2}$ World Economic Forum. The Global Competitiveness Report: 1997. Geneva Switzerland (1997) p. 18 21.

3 Cf. David L. Lindauer and Michael Roemer. Asian and Africa: Legacies and Opportunities for Development. San Francisco, CA: Institute for Contemporary Studies. 
And most important, all of these economic changes had been achieved with only a relatively small deterioration in the measured income distribution.

But by the end of the decade a very different view emerged. Although a number of the Asian miracle economies were severely affected by the Asian financial crisis, Indonesia fared worst, quickly turning from a "star performer" to the "sick man" of East Asia. Its economy proved less resilient to the Asian financial turmoil than other Asian economies and its recovery has been slower and more hesitant than that of the other affected Asian countries.

Given Indonesia's economic track record over the period 1985 to 1997, some observers thought it puzzling that the economy would suffer such a severe and sudden collapse when faced with an external shock. ${ }^{4}$ A number of the stylized models that have been put forward to explain the depth and spread of the Asian crisis seem particularly relevant to Indonesia.

For example, Krugman ${ }^{5}$ hypothesized that a prime cause of the crisis could be found in the "financial excess" that characterized much of the analysis about the newly emerging Asian economies. This analytic exuberance led many observers to overlook the institutional and policy problems that remained unaddressed, perhaps because the analysts assumed that these problems would eventually be rectified as economic progress made these shortcomings more obvious and the needed reforms less painful. Krugman also pointed out that often there was a willingness on the part of government to guarantee, explicitly or implicitly, the rate of return on projects of dubious economic value. Such guarantees enticed banks to over-invest in risky and unsound projects leading to an overpricing of assets. Eventually some external event, or a realization by the government itself that it has a limited capacity to finance the potential cost of future bailouts, results in a drop in asset prices. Such an asset price correction inevitably leads

\footnotetext{
${ }^{4}$ For example, Goldstein, et al., found that their leading indicators failed to anticipate the Indonesian crisis even though these same indicators correctly ranked Thailand, South Korea and the Philippines as countries vulnerable to financial crisis. Cf. Morris Goldstein, Graciela L. Kaminsky, and Carmen Reinhart, Assessing Financial Vulnerability: An Early Warning System for Emerging Markets. Washington DC: Institute for International Economics, June 2000. Similarly, Furman and Stiglitz report that Indonesia's crisis was the least predictable within a sample of 34 troubled countries. Cf. Jason Furman and Joseph E. Stiglitz. "Economic Crisis: Evidence and Insights from East Asia." Brookings Papers on Economic Activity; Washington DC, 1998.

${ }^{5}$ Paul Krugman. "Bubble, boom, crashes: theoretical notes on Asia's crisis." Mimeo. MIT (1998).
} 
to a contraction of liquidity and insolvency for the banks that had financed these risky projects. As interest rates rise, banks are less able to accommodate borrowers who fall in to arrears, forcing the banks to eventually call in these outstanding loans. These elements create the beginning of an inevitable asset price correction and a downturn in economic activities. Although posited these ideas as a general description of the Asian crisis, it mirrors many of the events that actually occurred in Indonesia.

Radelet and Sachs sketch a different scenario, placing emphasis less on domestic policy failures and more on the inherent instability of the open economy model. In their view the trigger for a crisis such as the Asian crisis, lies in the vulnerability of the open economic system to financial panic. ${ }^{6}$ A sudden withdrawal of funds by foreign investors triggers a major capital outflow that precipitates the crisis. The immediate cause for such a chain of events is the realization that a country's short-term obligations exceed the liquidation value of its assets, leading investors to "run for the exits" in an attempt to be the first to cash out their assets. This very action leads to a sharp depreciation of the exchange rate and a sharp contraction in economic activities, giving credence to the very concerns that triggered the action. When government then adopts a tight fiscal and monetary stance, as Indonesia did in an effort to stabilize the situation, the credit crunch results in a sharp rise in interest rates that increases bankruptcies and bank insolvency while doing little to stabilize the exchange rate.

Despite the differing descriptions of the origins of the financial crisis the core of both explanations is the assumption that the economic system was less well managed than the major economic indicators suggested. If so a closer reading of policy actions over the period 1980 to mid-1995 should reveal a number of fundamental weaknesses that undermined the economic fundamentals. Indeed a review Indonesia's economic reform effort suggests precisely this. Throughout the reform period one finds a number of seemingly minor policy missteps that were largely shrugged of in the euphoria of Indonesia's rapid economic growth. Eventually however these small missteps resulted in

\footnotetext{
${ }^{6}$ Steven Radelet and Jeffrey D. Sachs. "The onset of the East Asian financial crisis." Cambridge, MA. National Bureau of Economic Research (1998).
} 
a severely weakened economic framework that collapsed in the storm of the Asian financial crisis. $^{7}$

A useful analogy is the concept of "self-organized criticality," an idea that has its roots in chaos theory. Buchanan, ${ }^{8}$ who has applied the idea of "self-organized criticality" to such diverse phenomena as earthquakes, stock market crashes and forest fires, notes that many events have distributions that follow a power law: there many small earthquakes, but few big ones. But the minor events may well presage a larger and more serious event. This kind of scaling characterizes numerous systems that are poised on the edge of change systems that are in effect in a "critical state." As applied to an economic system, the idea of self-organized criticality suggests that an economy can tolerate many small shocks, all of which are seemingly shrugged off with little long-term impact. But eventually there is a major shock whose impact is less easily overcome, in part because the previous small shocks have undermined the strength of economic framework and its ability to handle a major shock.

Whether the idea of "self-organized criticality" has general applicability to economic systems remains to be seen but the idea provides an apt description of the evolution of the Indonesia political and economic situation during the 1990s. What appeared to many to be an economy that had a reasonable record of successful economic management was in fact a political and economic system whose strengths and institutional base had been progressively weakened through small actions or inactions. While none alone seemed to forecast difficulty the cumulative effect of this neglect to deal with emerging weaknesses set the stage for a major economic collapse. Hindsight makes it is easy to see the growing weakness of the political and economic situation and also leaves unanswered the question why so many analysts, including international credit rating agencies as well as private investors who observed some of these policy missteps first-hand, failed to recognize the fragility of the economy in time. There seems to be no easy answer to this puzzle.

\footnotetext{
7 See Lloyd R. Kenward, “Assessing Vulnerability to Financial Crisis: Evidence from Indonesia,” Bulletin of Indonesian Economic Studies. Vol. 35 (3) December 1999, pp. 71-95, who reaches a similar conclusion. 8 Mark Buchanan. Ubiquity: The Science of History or Why the World Is Simpler Than We Think. London, UK: Weidenfield and Nicolson (2000).
} 
In what follows we describe economic developments in Indonesia and the evolution of Indonesia's economic reforms, highlighting the policy inconsistencies that arose over this period. These policy missteps did not appear critical at the time until one recognizes that they were accompanied by an erosion of the political support that the economic policy team had enjoyed for many years. To a large extent it was this erosion of support that led to a failure to extend the reforms and helps explain the incapacity of the Indonesian economy to deal effectively with the Asian financial crisis. Obviously hindsight provides considerable help in such an analysis but this is not intended as an exercise in "schadenfreude." Rather the lesson to be learned is that the basic macro-economic indicators often fail to reflect the growing weaknesses (or strengths) of the national political and social infrastructure that provide the essential framework for sustained economic growth. The collapse of the Indonesian economy illustrates the need for combining measures of globalization and international integration with a concerted effort to strengthen institutional framework such as creating an independent and reasonably competent judiciary, strengthening corporate governance and banking sector oversight, together with a political system open to change. Indonesia's progress on reforming its economic structure blinded many observers to its total disregard for improving the political, education, and institutional base that is a prerequisite for sustained economic growth.

\section{The Early Economic Reforms}

Indonesia's economic reforms have been extensively reported and studied, so only a brief summary is presented here. ${ }^{9}$ After gaining power the new Soeharto government and its economic team turned their attention the issue of economic stabilization. Once that was achieved the economic team pushed for the adoption of three policy principles that further earned the team international respect: the "balanced budget rule," the move to an "open capital account," and the adoption of an adjustable pegged exchange rate.

\footnotetext{
9 Cf. Wing Thye Woo, Bruce Glassburner and Anwar Nasution. Macroeconomic Policies, Crises, and Long-term Growth in Indonesia, 1965 - 90. Washington, DC. World Bank Comparative Macroeconomic Studies (1994); Joseph J. Stern, "The Development of a Modern Economic State," in Pembangunan Nasional: Teori, Kebijakan, dan Pelaksanaan. Jakarta, Indonesia: Fakultas Ekonomi Universitas Indonesia. (1997), Vol. II, pp. 729 - 744; and the thrice yearly updates on Indonesian economic developments published in the Bulletin of Indonesian Economic Studies.
} 
The "balanced budget" prevented government from resorting to deficit financing and served to shield the Minister of Finance from excessive financing demands that arose from time to time, a shield that proved even more important as the economy became more robust and financially secure, which made proposals for more grandiose expenditure targets more feasible. Despite the nominal adherence to the "balanced budget" rule the government resorted to "off-budget accounts" to fund numerous politically motivated projects, to help finance the government's re-election campaigns, and to fund persistent public enterprise sector deficits that were financed by borrowing from the state banks. While the "balanced budget rule" prevented any substantial reliance on domestic deficit financing, in reality the rule was less and less rigorously enforced and in the process becoming less of rule and more of a slogan that hid the true budgetary situation. ${ }^{10}$

In 1971 the government eliminated all controls on foreign exchange transactions. Since nearly all developing economies, and even some of the more advanced countries, still restricted foreign exchange transactions, this was considered a highly controversial move, with some observers expressing concern that this move would undermine the hard won stabilization efforts. The economic team argued that this step was necessary because the open capital account would provide a further brake on monetary policy by ensuring that any monetary mismanagement would show up almost immediately in an outflow of foreign exchange. ${ }^{11}$ Despite the dire warnings Indonesia never wavered from its commitment to an open capital account, a policy that was maintained even when Malaysia decided to restrict capital movements. Some analysts suggested that Indonesia should follow suit but the economic team, some of whom had helped open the capital account some thirty years earlier, rejected this advise and the open capital account remains firmly in place.

\footnotetext{
10 Although it was common knowledge that there were off-budget expenditures, most notably those associated with the airplane industry managed by the Minister of Technology, later Vice-President and President, B.J. Habibie, the size of the off-budget expenditures were unknown, even to many senior policy makers. To that extent, the balance budget rule façade was a misleading index of fiscal discipline.

11 It may be seem puzzling that Indonesia could remove all foreign exchange controls and not face a serious currency collapse. However when this move was adopted in 1970, few Indonesians had significant rupiah resources to convert to dollars and the liberalization of the exchange control regime took place well before the era of large private capital flows so that there was little risk that a sudden capital inflow would appreciate the currency.
} 
The government also took steps to unify the exchange rate and then moved to set up a flexible pegged exchange rate system which sought to maintain the real international value of the rupiah by adjusting the nominal rate to reflect changes in domestic consumer prices relative to international prices of its major trading partners. ${ }^{12}$ Although at the time this was considered a reasonable exchange rate regime, and one that could provide sufficient flexibility for Indonesia's economic management, major exchange rate realignments rate were required in 1973, 1983 and 1986, each time to deal with impact of sharp change in world oil prices. But after the last depreciation Indonesia's real exchange rate remained reasonably competitive for a number of years avoiding the need for further sudden large changes in the value of the currency. ${ }^{13}$

The real rupiah exchange rate, shown in Figure 1, is based on a weighted average of the value of the rupiah against the US dollar, the Japanese Yen and German mark. ${ }^{14}$

Figure 1

Real Rupiah Exchange Rate Against the US Dollar

(First half of $1990=100$ )

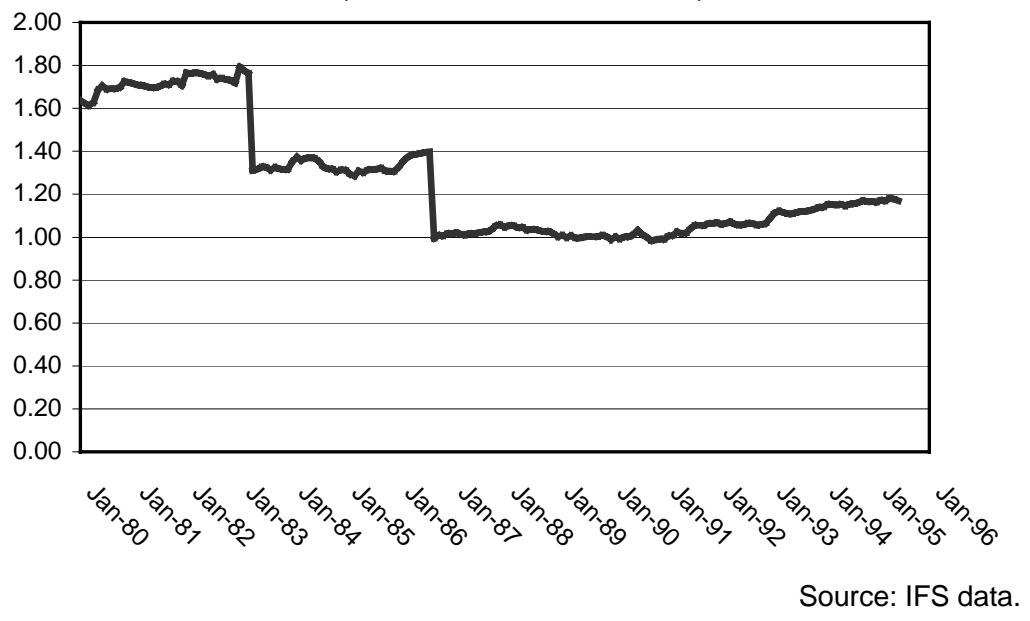

Note that the real exchange rate remained relatively constant from September 1986, when the rupiah was last depreciated, through the early part of the 1990s, when the rupiah began to experience some modest appreciation. But after 1993 the effectiveness of the

12 The exact weights used to set the daily rate within a moving band were never explicitly stated although there is evidence that a preponderance of weight was given to the US dollar.

${ }^{13}$ For a comprehensive analysis of the real exchange rate in Indonesia, see Steven Radelet, "Measuring the Real Exchange Rate and its Relationship to Exports: An Application to Indonesia." Cambridge, MA: Harvard Institute for International Development. Development Discussion Paper No. 529, May 1996. 
exchange rate policy weakened, allowing the rupiah's value to appreciate. The trade weighted exchange rate $(1990=100)$ appreciated by $16 \%$ in 1994 and by nearly $20 \%$ in 1996. This appreciation contributed to the slow down in manufactured exports growth that began to plague the economy and which, combined with a rapid rise in imports, resulted in a substantial deterioration of the current account deficit. This deficit, which had averaged about two percent of GDP over the period 1987 - 1994, rose to over three percent in 1995 and 1996.

In a recent paper Dueker and Fischer ${ }^{15}$ argue that the credibility of an exchange rate peg depends crucially on whether the market believes the pegging country's economy remains internationally competitive, given the appreciation of its real exchange rate. They conclude that appreciation of the currency, in this case the rupiah, relative to the dollar may appear sustainable during a period when many of the world's major currencies are appreciating relative to the dollar, but this is situation is perceived to become unsustainable when that condition is reversed. Hence, during the early part of the 1990s, when the U.S. dollar, which presumably had a large weight in Indonesia's currency basket, depreciated, reaching a record low in May 1995 against the Japanese yen, the appreciation of the Indonesian currency was not considered a serious policy flaw. But that situation reversed itself after May 1995, when the value of the yen began to depreciate against the dollar and the strength of the Indonesian currency began to raise doubt about the sustainability of the currency regime.

Indonesia's commitment to orderly movements in the exchange rate was so strong, and so well maintained over many years, that it lulled many borrowers into a false sense of security. Moreover, Bank Indonesia had set a very narrow range, $\pm 0.15 \%$ from the middle rate, for fluctuations around the central value that was adjusted to reflect the rupiah's real purchasing power. ${ }^{16}$ This narrow band, combined with frequent policy statements that reaffirmed the government's commitment to maintaining an adjustable peg, encouraged domestic investors to borrow offshore without hedging their foreign

\footnotetext{
14 The weights used were $40 \%$ for the US dollar; 40\% for the Japanese Yen; and $20 \%$ for the German DM. The "producer price index" was used to approximate changes in "world prices."

15 Michael Dueker and Andreas M. Fischer. "The Mechanics of a Successful Exchange Rate Peg: Lessons for Emerging Markets.” Discussion Paper No. 2829, Center for Economic Policy Research, June 2001.

${ }^{16}$ In fact, under the original Bretton Woods fixed exchange rate system all currencies were allowed to vary the value of their currency by $1 \%$ from their declared dollar parity value.
} 
exchange exposure. Over time Bank Indonesia began recognize the inherent risk that borrowers were exposed to and widened the bands five times between 1994 and 1997 in a belated effort to increase the implicit cost of foreign borrowing. But even after the first widening of the band, the spread between the buy and sell exchange rates was approximately $\pm 1 \%$ from the middle rate, narrow by international standards. Use of such narrow bands became increasingly anachronistic as other countries, including a number of developing countries, adopted wider bands and more flexible exchange rate regimes. Indonesia in fact failed to move aggressively towards a more flexible exchange rate regime and it was not until the 1997 the crisis that Indonesia was forced to set wider band before eventually adopting a floating exchange rate regime. ${ }^{17}$

In the 1980s, when private capital flows became more common, and when Indonesia had established a reputation as a reasonable stable and well managed economy, a difficulty in exchange rate regime became apparent - Indonesia had to manage increasingly large inflows of capital. In the first instance these inflows forced Bank Indonesia to purchase foreign exchange to prevent an appreciation of the currency, purchases that were paid in local currency. Such transactions increased the money supply and unless the increase was absorbed, would exacerbate inflation. Indonesia's inflation rate throughout much of the 1980 s and in to the 1990s was moderately high, ranging between 5 and $10 \%$, but was typically close to $9 \%$, about twice as high as in the inflation rate in neighboring Malaysia and Thailand. This unfavorable comparison strengthened the Government's desire to keep inflation below 10 percent, in effect setting an inflation target for Bank Indonesia's monetary policy. To mop of the 'excess liquidity' Bank Indonesia sold its own monetary instrument, the Sertifikat Bank Indonesia (SBI). The interest rate that Bank Indonesia paid on SBIs exceeded the interest return, after adjusting for currency depreciation, which it earned from its holdings of foreign exchange so that it sustained substantial losses from these operations. ${ }^{18}$ Fane for example estimates that the sterilization of capital inflows

\footnotetext{
17 Former Governor Soedrajat noted that each time the intervention bands were widened, the rupiah appreciated, leading borrowers to minimize the risk in increasing their unhedged foreign currency borrowing. Soedrajat Djiwandono, "Monetary Policy and the Banking System in Indonesia: Some Lessons.” Fifth India-ASEAN Eminent Persons Lecture, New Delhi, India, September 12, 1998.

18 Ross H. McLeod. "Indonesia's Economic Performance: An Assessment." Manuscript dated March 28, 1996.
} 
may have cost Bank Indonesia about Rp 1 trillion in both 1992 and 1993. ${ }^{19}$ To absorb the growing capital inflows, Bank Indonesia offered higher SBI rates, raising overall interest rates. These higher rates attracted more foreign capital while the higher domestic interest rates steered domestic investors to offshore financial institutions to fund domestic investments. In short, while the exchange rate system worked well initially, over time, as domestic and international conditions changed, the adherence to the relatively fixed exchange rate regime led to significant and large unhedged foreign exchange exposure by many Indonesian companies. These conditions would eventually bankrupt numerous companies and domestic banks. The policy stance adopted in the 1970s eventually created some of the very conditions that helped destroy much of the economy when the Asian financial crisis broke.

\section{The Active Reform Period.}

In the early 1980s the "New Order" government was ready to turn its attention to series of economic reforms that slowly transformed the economy and laid the basis for a decade of robust growth. Three major areas of economic policy were reformed during this active reform period, ${ }^{20}$ spanning roughly the decade of the 1980s. The reforms covered the fiscal system, trade regulations, and the financial system, and were carried out under the continued aegis of the "the economic team," that remained in charge control of the economic portfolios. Yet even as their success became apparent it also became clear at least to some observers that much remained to be done if the reforms were to become truly effective. Whether any further reforms, aimed at strengthening Indonesia's institutional infrastructure, would eventually have been undertaken and successfully implemented will never be know for by the early 1990s, this group of economists had lost much of its political support and found itself increasingly replaced by more nationalistic and technocratic bureaucrats, who often did not share the view that the economic reforms already in place needed further extension and strengthening.

\section{A. Fiscal Reforms.}

19 George Fane. "Survey of Recent Developments." Bulletin of Indonesian Economic Studies, Vol. 30 (No. 1) April 1994, p. 3.

${ }^{20}$ Iwan J. Azis, "Indonesia" in John Williamson (ed) Political Economy of Policy Reform, Washington, DC: Institute for International Economics (1994) suggests that the reform effort fell in to three periods: the 
In the early $1980 \mathrm{~s}$ the government began to modernize Indonesia's tax system. The immediate impetus was the realization that the economy was highly dependent on oil and gas revenues not only for its foreign exchange earnings but also for its domestic revenues. The economic team understood that the development of a modern economy required not only a diversification of productive capacity and exports but also the development of a stable tax base, and that meant a tax system less dependent on the energy sector. It was also clear that a highly complex tax system, with high marginal rates, was not only difficult to implement and destructive of economic efficiency, but open to considerable corruption. In 1983 a revised tax code was ready for adoption. It reduced the number of rates to three $(15,25$, and 35 percent $)$ and moved to a largely selfreporting income tax. ${ }^{21}$ To increase compliance and deflect criticism that the tougher enforcement of the tax laws would disproportionately harm the lowest income earners, the cutoff point for taxable income was doubled, removing many of the low-income wage earners from the tax net.

Two years later, in April 1985, a value-added tax on domestic manufactures, using a single rate of 10 percent (in addition to zero rated activities) with very few exceptions was introduced. It replaced a complex system of domestic and sales taxes on imports that had created an anti-export bias in the fiscal system and favored the upper income groups. It may well have been as Radius Prawiro, one time Coordinating Minister for Economy and Finance, noted "...the most important step in bringing equity to the tax system was the elimination of a plethora of exemption and loopholes." 22

The government also decided to eliminate the tax holidays for foreign investment, a reform that not only equalized the incentives for different projects but served to reduce the opportunities for rent seeking and it may well. This step was certainly the most controversial in the entire tax reform effort. Numerous observers argued that elimination of tax holidays doomed Indonesia's still nascent effort to attract foreign investment but the economic team stayed the course even when the levels of foreign direct investment

pre-reform period, from 1980 to 1982 ; the early reform period from 1983 - 86; and the active reform period, from $1986-89$. In the 1990s the reform agenda was allowed to lapse.

${ }_{21}$ In 1995, the rates were further reduced to 10,15 , and 30 percent.

22 Radius Prawiro. Indonesia's Struggle for Economic Development: Pragmatism in Action. Kuala Lumpur, Malaysia: Oxford University Press (1998) p.235. 
declined in the first year following the adoption of the new tax laws. Over time, as supporting policy reforms were put in place, foreign investment levels recovered and eventually began to rise rapidly, as is shown in Table $2 .{ }^{23}$ In fact Indonesia enjoyed a higher rate of FDI growth than other Asian destinations, most of which continued to grant tax holidays.

Table 2

Direct Foreign Investment

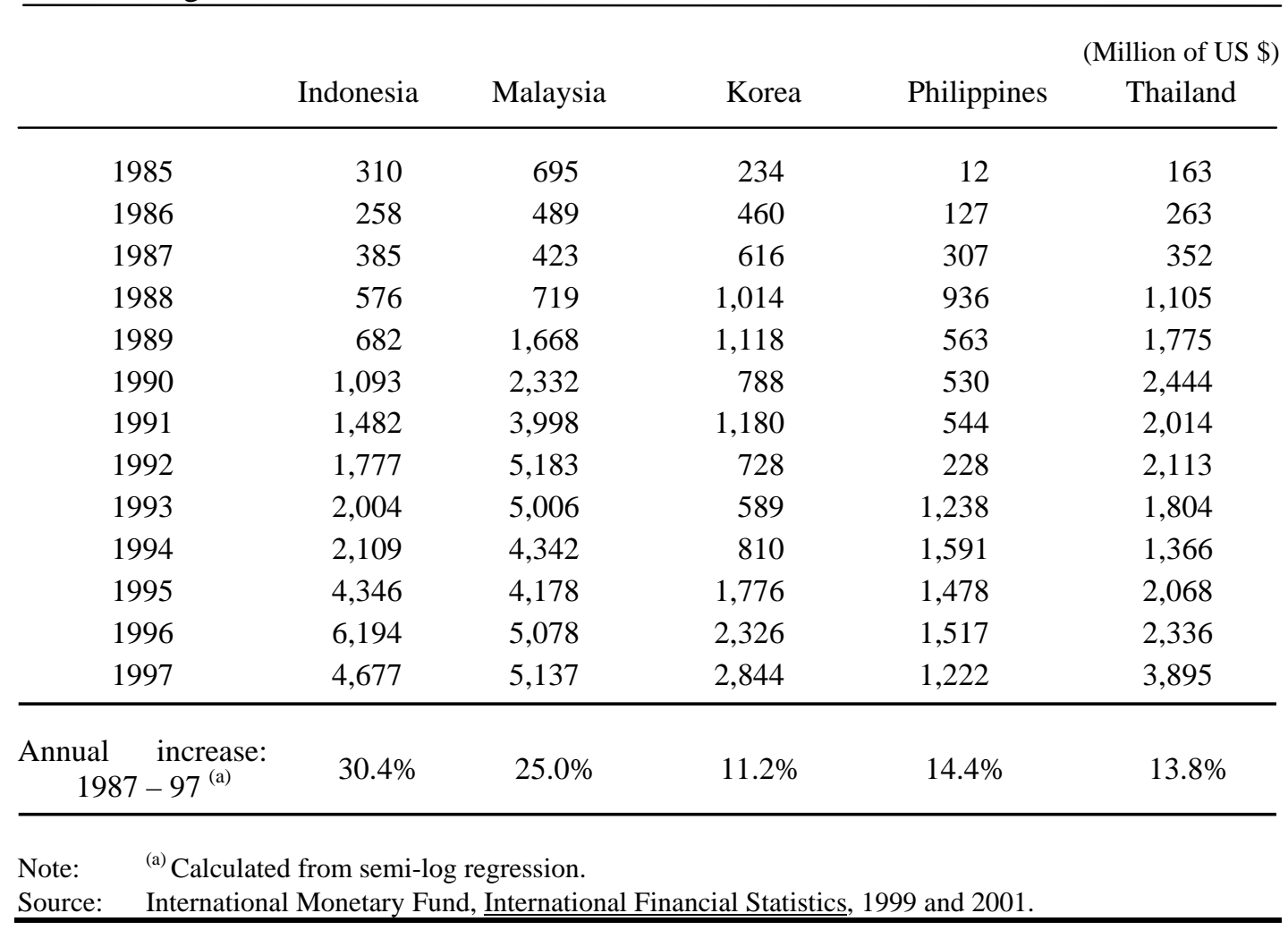

The fiscal reforms focused next on a reform of property taxes. The increasingly rapid pace of economic development and the growth of the urban centers had increased the value of urban properties but as these higher values were not reflected in the property tax assessments, they increased property values generated substantial profits for the landholders but little revenue for government. While some improvements in the property tax system were achieved the final result fell short of what was needed to set up an

${ }^{23}$ It is true that foreign direct investment levels rose throughout much of Asia and that much of the foreign direct investment in Indonesia was related to gas and oil exploitation. However even after eliminating some of the large natural resource exploitation projects, there was a substantial rise in foreign direct investment inflows. 
equitable property tax system. In fact most efforts to reform and strengthen the fiscal system had came to an end by the early 1990s. ${ }^{24}$

Despite all the shortcomings of the fiscal reform effort, it yielded a substantial increase in government revenues and led to a diversification of revenue sources. Perhaps most notable was the shift in the ratio of non-oil and gas revenue receipts as a proportion of GDP, which rose from slightly over eight per cent in 1985/86 to nearly $12 \%$ in 1994/95. Over this same period income tax receipts increased ten-fold, so that by the middle of the decade income tax receipts began to exceeded revenues from the oil and gas sector. The contribution of the value added tax also rose dramatically increasing by seven-fold over the period 1985 to 1995, albeit because of an extension of the coverage introduced in 1994. On the expenditure side, the fiscal reforms led to a reduction or elimination of numerous subsidies that burdened the government budget and the economy including reductions in the numerous subsidies to agriculture. One subsidy that proved more difficult to tackle was the energy subsidy. Like many resource rich economies, there was a strong belief that low energy prices were important for development while the kerosene subsidy was justified on poverty alleviation grounds since this was the major cooking fuel for low-income households. However even here the economic team, bolstered by a number of studies that showed the true costs and benefits of the energy policy and demonstrated that the kerosene subsidy was an inefficient poverty alleviation tool, made progress. In 1995 the government accepted a series of proposals to raise energy prices, bringing them more in line with world prices. $^{25}$

Despite some major improvements it was clear that the reforms left much work undone. Indonesia's tax effort remains relatively modest in comparison to other similarly situated developing countries a result that is partly due to the modest tax rates put in place but also reflects the failure to strengthen the tax collection system. ${ }^{26}$ Large taxpayers continued to negotiate tax bills that reduced the amount paid to a level well below the

${ }^{24}$ Cf. Jay K. Rosengard. Property tax reform in developing countries. Boston, MA: Kluwer Academic Press, 1998.

${ }^{25}$ By 1996, for example, domestic gasoline prices were higher than their equivalent world price. In effect users of motor fuels were taxed at a level that offset, at least in part, the environmental costs of motor vehicle use. Unfortunately the policy of periodically fixing energy prices, rather than allowing them to float pari passu with international prices, eventually led to a large subsidy on energy reappearing as the world price rose and domestic prices were not adjusted. This remains a persistent problem. 
actual amount due or even to nil, and evasion of the value added tax was common. Not only did government lose revenues but the tax reform effort was seen as having increased the burden on some while leaving the large taxpayers unscathed.

\section{B. Trade policy.}

Until well in to the mid-1980s Indonesia's trade regime favored import substituting activities through a wide variety of policy instruments including ad valorem import duties which ranged from zero to 200 percent and which were further bolstered by a substantial number of specific rates as well as non-tariff import restrictions that covered almost 35 percent of total imports by value. A 1984 study concluded that the weighted average effective rate of protection afforded the manufacturing sector was 410 percent compared to an average effective rate of protection of 215 percent for other non-oil sectors and of 17 percent for capital goods manufacturers. ${ }^{27}$ Moreover in a further effort to stimulate the use of local intermediate products, manufacturers of finished products were required source domestically produced components regardless of cost or efficiency while investment licensing protected domestic producers from domestic and international competition. Exports of a numerous goods were restricted to ensure that there were adequate local supplies for domestic needs while other restrictions, notably on logs and rattan, were put in place to encourage domestic downstream processing. To give some relief from import duties on imported raw materials used by exporters, an export certificates program had been instituted but poor implementation turned that program into a direct subsidy for selected exporters. ${ }^{28}$

Not surprisingly this trade regime generated little or no growth in manufactured exports leaving Indonesia highly dependent on oil and gas exports. With the end of the second oil boom, the economic team turned its attention to reforming the trade regime. This was

\footnotetext{
26 Indonesia's non-oil tax revenues form about 10 percent of GDP, low by regional standards.

27 Richard Barichello and Frank R Flatters, "Trade Policy Reform in Indonesia," in Dwight H. Perkins and Michael Roemer (eds.) Reforming Economic Systems in Developing Countries. Cambridge, MA: Harvard Institute for International Development (1991) p. 276-77.

28 When in March 1985 Indonesia became a member of GATT, it was determined that the export certificate program was in violation of GATT rules forcing the program to be formally ended in June 1986.
} 
a daunting task because a careful inventory of the various protectionist elements found them to be "... extensive, complex, and mutually reinforcing." 29

The first salvo in dismantling the protectionist policy was announced in April 1985 when the government issued a number of decrees dealing with the administration of imports and exports. It was hoped that these measures, largely administrative in nature, focused on simplify the trade regulations would reduce the cost and time required to clear goods through Indonesian ports. Restrictions on inter-island shipping were eliminated or eased, facilitating domestic trade as well as economic integration. Greater use of foreign shipping was allowed, port operations were extended to twenty-four hours a day, and a private company Swiss, Société Générale de Surveillance (SGS), was assigned the task of assessing duties on all imports valued in excess of $\$ 5,000$.

Next the economic team turned its attention to reforming the industrial policy, a policy shift that was spurred in part by a realization that the import substituting industries were highly inefficient and unable to compete in the world markets. But there was also a realization that only with the establishment of efficient labor-intensive activities would sufficient new jobs be created to absorb both the new entrants into the labor force as well as the large pool of underemployed workers. In May 1986 the government announced a second set of trade deregulations that provided a strong and clear statement of the new development strategy. Numerous non-tariff barriers were either removed or severely curtailed, exporters were given access to a duty drawback facility, the country's first export processing zones were established, and numerous tariffs were slashed. ${ }^{30}$

The trade liberalization process continued over for the next decade with indeed additional trade reform measures announced each year, generally just before the annual donors meetings. $^{31}$ Over time these reforms removed most of the remaining non-tariff barriers and further simplified trade related administrative procedures. Perhaps most important the reforms reduced the nominal rate of protection on manufactures to less than 10

\footnotetext{
${ }^{29}$ Radius Prawiro, op cit. p. 268. In fact it took a substantial research effort to compile a comprehensive inventory of the tariff and non-tariff barriers.

${ }^{30}$ The duty drawback scheme was initially seen as a model of efficiency and honesty. Over time it became less efficient and evidence accumulated that corruption had again crept in to the process.

31 The timing was undoubtedly meant to influence the donors by providing evidence of Indonesia's continued commitment to trade deregulation, but it also played in to the hand of the more nationalistic
} 
percent in 1994, while the effective rate of protection fell to 20 percent $^{32}$ by mid-1990 and to six percent by September $1997 .^{33}$

As the bureaucratic hassles and the costs of importing were reduced foreign producers became more willing to locate production facilities in Indonesia. This had the desired dual effect of forcing domestic producers to face some measure of international competition, enhancing their own competitiveness, and of creating much needed new employment opportunities in the export-oriented sector.

While the trade reforms were initially seen as a series of bold moves, it soon became clear that they had not tackled the protection offered to a number of important sectors. Powerful political constituents or "well-connected" business groups often controlled these sectors. The economic team realized that if the reforms were to be truly effective they had to be extended to deal with some of these vested interests but efforts to extend the trade reforms were increasingly deflected by President, acting on behalf of the vested interest. Two classic examples was the treatment afforded to the automobile and to the steel sector.

While there had been some efforts to reduce the protection offered to automobile industry, consisting largely of automobile assembly rather than manufacturing, no real progress had been made in scaling back the protection afforded this highly profitable privately owned monopoly. Much the same was true of the monopoly on steel, a sector dominated by a state-owned company, PT Krakatau Steel. After some half-hearted measures to open up the steel sectors were put in place, government reversed tracks and effectively raised the level of protection to the steel industry. Under the guise of controlling "dumping" and the imports of "low quality steel" the government, in July 1992, increased the import surcharge on steel products. ${ }^{34}$

elements in the society who saw it as evidence that the entire deregulation process was driven by a desire to please foreign donors rather than as an effort to improve domestic economic conditions.

32 The average nominal tariff was calculated by the World Bank using import weights. World Bank. Country Economic Memorandum - 1995, p. 40.

33 Stern, op. cit., p. 736.

34 Bisnis Indonesia, March 21, 1997. The report also provides an interesting insight into how "dumping" was defined by some members of the business community. Pak Mangoensoewargo, director of PT Krakatau Steel, was quoted as saying that the low quality steel from East European mills was detrimental to Indonesia's development because "[t]hey do not care about the quality of their products." He contrasted 
Numerous export controls covering a wide range of primary products, including timber, plywood, vanilla, palm oil, cloves, and oranges, also remained in place. From time to time proposals were put forward to reduce or eliminate such controls, notably on garlic and wheat, but these efforts were either turned aside or modified so that their impact was sharply limited. It was no coincidence that these monopolies primarily benefited the Soeharto children or a small clique of largely ethnic-Chinese businessmen, all of whom were well connected to the first family. ${ }^{35}$ The post-1993 election cabinet saw a shift of political power away from the economic technocrats to a group of nationalistic and technologically oriented ministers. Why the President began to turn away from the economic team that had served him, and his country, so well for so long is not clear but it is clear that this shift in political power signaled that serious further reforms would have a difficult time.

Two subsequent policy decisions provided convincing evidence that the government's commitment to trade reform had waned. First, Bambang Trihatmodjo, President Soeharto's second son, together with Prayogo Pangestu a business tycoon and close family and friend, and the Marubeni Corporation of Japan, undertook construction of Chandra Asri, a large petrochemical plant. The government had been given assurance that this plant would require no tariff protection over and above the levels already in place. But as the facility neared completion the plant's owners asked for 35 to $40 \%$ tariff on imports of competing olefin products. Minister of Finance, Mar'ie Muhammed, refused to grant such protection, arguing that this would raise the cost of textiles, and further damage Indonesia's competitiveness. For this effort he was summarily removed as chairman of the tariff review committee and a new chairman, who quickly granted the requested protection, was installed. ${ }^{36}$

this to "[t]he steel from Japan, with a higher price, that is welcome. It does not create problems, because the markets are different."

35 Perhaps the most egregious of the agricultural monopolies was the clove monopoly, established at the end of 1990, which was run by Tommy Soeharto, President Soerharto's youngest son. Billed as an effort to protect the income of the clove farmers, it merely served to sharply the income of the clove producer while accumulating huge clove stocks, with the cost eventually borne by Bank Indonesia. Schwartz calls it "arguably the most egregious display of crony businessman greed...." Adam Schwarz. A Nation in Waiting: Indonesia in the 1990s. Australia: Allan and Unwin, Pty Ltd. 12994, p. 153.

36 The $25 \%$ tariff on ethylene and propylene forced Petrokimia Nusantara Interindo (PT Peni) a BP chemical unit that manufactures polyethylene, to agree to buy ethylene from Chandra Asri. But PT Peni, 
Second, in February 1996 a presidential decree gave PT Timor Putra Nasional, a company controlled by President Soeharto's youngest son, a three-year exemption from luxury taxes and import duties, benefits given to encourage the development of a 'national car,' the Timor. In return for the concessions granted, the company agreed that by the end of the first year $20 \%$ of the car's components would be locally sourced, a proportion that was to rise to $40 \%$ by the end of the second year, and to $60 \%$ by the end of the third year. The original concept called for the car to be produced domestically with technical assistance from South Korea's Kia motors. But in an extraordinary move that clearly illustrated the extent and depth to which cronyism and family business involvement now constrained economic reforms, a Presidential Decree issued in June 1996 stated that the Timor would be assembled in Korea, with parts to be shipped from Indonesia to Korea. This, it was argued, meant that the local content requirement had been met even though the vehicle was now fully assembled in Korea. ${ }^{37}$ In fact there was no capacity to manufacture the parts locally and ship them to Korea, so that in the end the "national car" was now simply imported fully assembled from Korea. But despite these setbacks the Timor continued to be fully exempt from duties and taxes. ${ }^{38}$ Many senior government officials recognized that the "national car policy" would be considered a violation of Indonesia WTO recently signed commitments, and worked to find a face saving compromise but their efforts were turned down by the President. Eventually the WTO ruled against Indonesia. Sales of the Timor remained anemic and in a last ditch effort to support Tommy's venture, the government forced all government agencies and ministries to buy the Timor. ${ }^{39}$ The entire national car experiment was ended by the

\footnotetext{
jointly owned by BP Chemicals and Sigit Harjojudanto, another son of President Soeharto, then found its products uncompetitive, leading it to apply for, and receive, higher tariff protection.

37 It had become necessary to adopt this subterfuge when it became clear that none of the local assembly facilities would be made available to the new car company. It was also suggested that around 1,000 workers would be sent as trainees to Korea but Korean labor unions quickly put an end to that idea. See Chris Manning and Sisira Jayasuriya, "Survey of Recent Developments," Bulletin of Indonesia Economic Studies, Vol. 32, No. 3 (August 1996) pp. 18 - 19.

38 In another effort to safe face, and to obtain WTO approval for the national car scheme, PT Timor Nasional was obliged to deposit funds, equivalent to the duties and taxes it would pay it if it could not meet the local content targets, with a designated bank. These funds would be redeemed if the Timor could meet the third year target on local content. But in typical fashion PT Timor Nasional did not have to raise the funds in the market. Some state banks were directed to provide the necessary funds, at below market interest rates, to the company.

${ }^{39}$ Financial Times, June 5, 1997.
} 
financial crisis but not before this episode had caused a further weakening of Indonesia's reputation and revealing the extent of nepotism and corruption.

There was one final hope. The economic team saw Indonesia's commitments under AFTA (the Asian Free Trade Area) as a possible avenue to continue the deregulation efforts. Indeed the May 1995 package seemingly set a firm timetable for Indonesia to carry out its commitments under AFTA. If that deregulation package had been implemented it would have created a truly low tariff economy with only three rates zero, 5 and 10 percent - and with an average tariff well below 10 percent although the tariff reductions would not take place for some years. ${ }^{40}$ But the onset of the financial crisis derailed this final effort and the proposed tariff reductions have never been implemented.

Despite the numerous shortfalls and weaknesses, the trade deregulation program produced significant results. Export growth accelerated so that the exports/GDP ratio rose from $23 \%$ in 1985 to $26 \%$ by 1990 , and to $28 \%$ by 1997 . The composition of exports, shown in Figure 3, changed dramatically. In 1985, when the reform drive began, primary products such as rubber, coffee, tea, tin and aluminum, accounted for close to one-half of total non-oil exports. By 1997 their share had fallen to less than one quarter even though their absolute value had increased. Exports of garments, textiles, footwear, electrical products, paper and paper products, plywood, and furniture all grew rapidly, leading to a significant diversification of the export commodity structure.

\footnotetext{
${ }^{40}$ Anwar Nasution. "Survey of Recent Developments." Bulletin of Indonesian Economic Studies. Vol. 31, No. 2, (August 1995) p. 13.
} 


\section{Figure 3}

\section{Exports: Total and Non-oil/Gas}

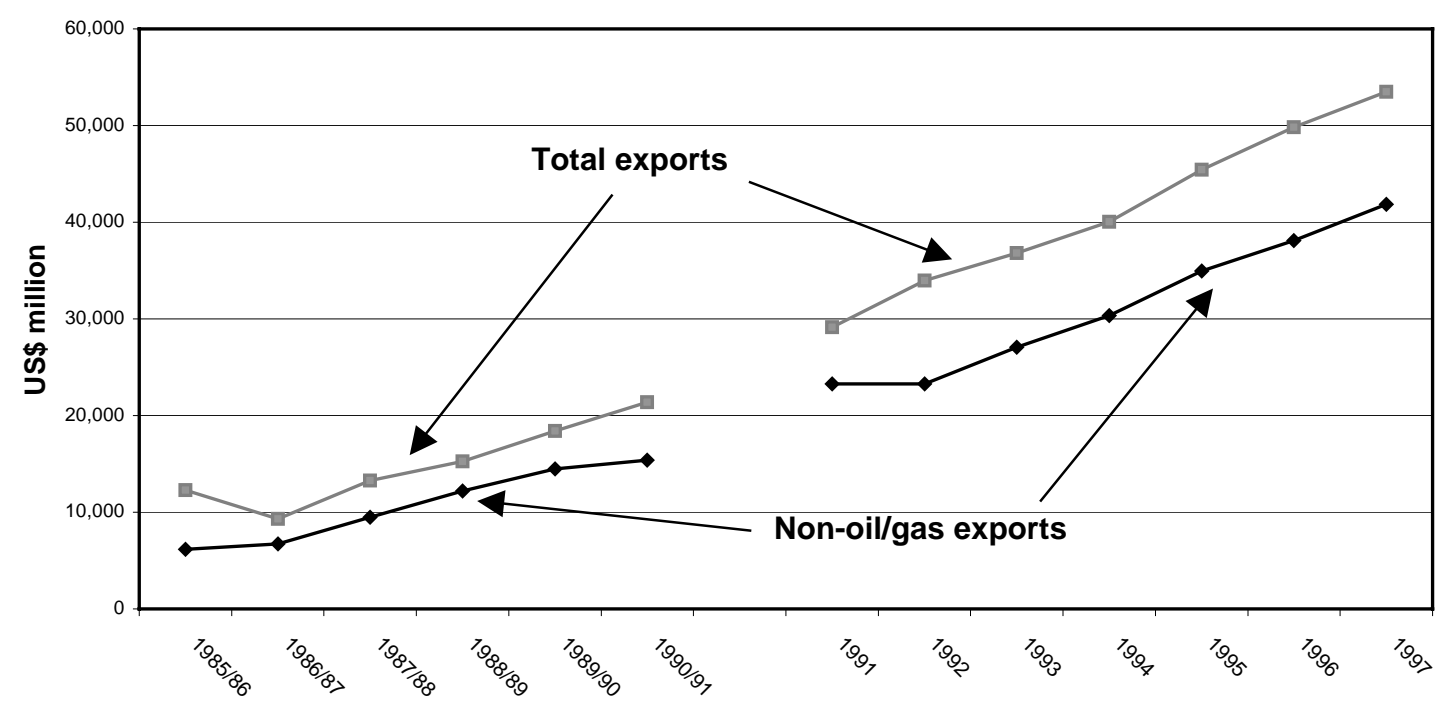

Source: 1985/86 - 1990/91: Bank Indonesia 1991 - 1997: Biro Pusat Statistik

Moreover the trade reforms spurred numerous foreign companies to locate their export processing plants in Indonesia, a development that increased competition in the manufactured sector in addition to helping raise export levels. To help attract foreign investors Indonesia adopted more open towards such investments. Like many developing countries Indonesia had traditionally viewed foreign private investment skeptically, associating foreign ownership with exploitation rather than with development. As a result a variety of regulations controlled such investments and only a few sectors were open to foreign investment with the degree of foreign ownership restricted. More onerous, even after foreign investors had established and operated a plant, they expand capacity beyond the originally sanctioned level required further approval. Combined with the import substituting biased trade policies, these restrictions helped create an industrial sector characterized by low labor intensity, high costs, and a lack of international competitiveness. Concurrent with the first trade reform measures of 1985 some small efforts were made to improve the investment climate but it was the May 1986 deregulation package that significantly changed the laws governing foreign investment. A simplification of the investment application process reduced the number of licenses needed from 26 to 13 and the same reform package increased the permitted level of 
foreign ownership to $95 \%$ for firms engaged in exporting or selected other activities. Joint ventures were given nearly co-equal treatment with local firms in the domestic credit market. As with the trade reform process, additional reform measures were announced over the years, further easing the regulations governing foreign direct investment. Perhaps most important there was a progressive reduction in the number of sectors closed to foreign investment so that by June 1994 nearly all sectors were open to foreign investors. ${ }^{41}$

The response to the improvement in the investment climate was fairly dramatic and allowed Indonesia to take advantage the increasing foreign private capital flows in the global market place. Realized foreign investment rose from US\$0.3 billion in 1985 to US $\$ 4.3$ billion in 1995. Much of this investment went into export-oriented activities although as might be expected, a substantial portion found its way to the highly protected sectors. Such flows of capital to protected sectors has been criticized on the grounds that such investments were less beneficial to the economy than the use of such funds in more open sectors. While true, even the flow of capital, and new technologies, to the protected sectors helped create a measure of domestic competition in such activities, generating pressures to reduce costs and maintain productivity in competing firms. The presence of foreign investors increased the pressure to maintain or increase protection, special pleadings that often received the implicit (and at times explicit) support from their own government.

\section{Reform of the financial sector.}

Concurrent with the work on trade reforms the economic team turned its attention to the financial sector. At independence Indonesia had nationalized the Dutch-owned banks that dominated the banking structure, merging them into one institution, Bank Negara Indonesia (BNI). It soon became apparent that this monolithic structure was unworkable. In 1968 a central bank was created and BNI was split in to five state-owned banks but various regulations continued to ensure that the state banks still dominated the financial sector. Interest rates were controlled and there were numerous programs that were meant

\footnotetext{
${ }^{41}$ The same package also opened up a further nine sectors - sea ports; electricity generation, transmission and distribution; shipping; civil aviation, provision of drinking water; railway services; nuclear power generation; and mass-media - to foreign private investment.
} 
to ensure the flow of credits to favored sectors. Bank Indonesia itself gave direct credits to certain enterprises in addition to giving liquidity credits to the banking system, primarily to the state banks, to promote a range of targeted activities. As a result Bank Indonesia and the state-owned banks supplied between 85 to 90 percent of all bank credit. The first serious efforts to reform the financial sector began in 1983 when restrictions on the allocations of bank credits and state bank interest rates were eliminated. Bank Indonesia reduced its dominant role in the refinancing of bank loans and used the Sertifikat Bank Indonesia (SBI) as a means of improving monetary control. By early 1990 the bulk of Bank Indonesia's liquidity credit arrangements had ended. Although the state-owned banks continued to dominate the system an immediate outcome of these initial reforms was a substantial increase in interest rates paid on deposits and charged for loans, measures intended to improve the allocation of scarce capital.

In late 1988 the government initiated a major process of deregulating the financial markets. The licensing regulations for new banks were eased while the opening of new branches and entry of foreign banks in the form of joint venture banks was now permitted. Entry barriers for new privately owned banks were sharply reduced, the procedures for establishing branch banks was simplified, and the requirements for becoming a foreign exchange bank were relaxed. The banking system could now offer a range of new financial services and instruments while the special privileges and responsibilities of the state-owned financial institutions were reduced. Reserve requirements on all deposits were lowered to two percent reducing the spread between borrowing and lending rates. ${ }^{42}$

These reforms profoundly changed both the growth and the structure of the banking system as well as on the services they provide. The less stringent ownership requirements combined with the relatively small capital base needed to establish a bank, led to a dramatic increase in the number of banks. The number of private domestic commercial banks rose from 63 in 1988 to 165 at the end of 1995, leading to a sharp decline in the market share of the state-owned banks. The number of foreign joint venture banks grew from a single such entity in 1988 to 41 by end 1995 while over the

42 Critics questioned the wisdom of the low reserve requirement, arguing that it contributed to the weakness of Indonesia's banks. Eventually Bank Indonesia decided to raise the reserve requirement. 
same period the total number of bank offices for all types of banks grew from 9,434 to 14,286. Many small bank branches were established in rural areas bringing banking services to a portion of the population that had previously had limited access, if any, to the financial sector. The ratio of total assets of financial institution plus securities to GDP, a good measure of overall size and growth of the financial sector, increased from about $26 \%$ in 1969 to $124 \%$ in 1994 . $^{43}$ Deregulation also contributed to a substantial rise in domestic savings and time deposits held by the banking sectors, providing a further stimulus to investment and growth.

Indonesia also moved to revitalize and strengthen another component of a modern financial system: the securities markets. The 1988 reforms permitted the opening of private securities markets while clarifying regulations governing insider trading and other unsound and unfair practices. After a series of reform measures announced in 1989 foreign shareholders could own up to $49 \%$ of the shares of any listed company, except commercial banks. This helped create a wider market for share ownership and served to attract foreign equity funds. A Capital Markets Decree was adopted at the end of 1990, setting forth regulations that were further strengthened and codified in the Capital Market Law passed in 1995. These changes, combined with the promotion undertaken by BAPEPAM, the capital markets agency, brought new life to the previously moribund Jakarta Stock Exchange. At the end of 1985, only 24 stocks were listed on the exchange with 0.57 billion shares. By 1996 there more than 246 stocks were listed with 59.41 billion shares while over the same period the market capitalization had increased from US $\$ 0.80$ billion to US\$77.4 billion.

The expansion of the banking system and of the capital markets quickly brought to fore the need for strong prudential regulations. Because the early efforts to market new shares were often neither professionally managed nor were the claims about likely future earnings and growth in the value of assets supported by any rigorous analysis, the economic team, with the concurrence of the President, agreed to a scaling back of the approval process for new issues, hoping to use the time gained to formulate a

43 David C. Cole and Betty F. Slade. Building a Modern Financial System: The Indonesian Experience. Cambridge, UK: Cambridge University Press (1998) p. 15. 
comprehensive set of prudential regulations for the capital market. ${ }^{44}$ In this they were generally successful but in the early 1990s a new problem arose when it became clear that there were serious weaknesses in the quality of banks assets. At the end of 1991, a policy note to the economic team warned that "The Indonesian banking system appears to be headed toward a crisis consisting of actual and rumored failures of many banks, massive deposit withdrawals from many private banks and a surge in demand for foreign exchange. ${ }^{\circ 5}$ Although these dire predictions were somewhat premature they indicate that that the reform of the financial sector was well designed, was far from complete. It become clear that at least some of the state banks were operating, as the policy memo noted, in "a free-wheeling, unconstrained manner...". A number of private banks fell far short of even the minimum prudential regulations that had been announced and two large private banks, Bank Summa and Bank Dutta, had to be rescued while it became clear that some of the state banks were effectively insolvent. ${ }^{46}$ BAPINDO, the state industrial development bank, lost some US\$600 million in a series of scandal ridden loans ${ }^{47}$ and a World Bank study noted that at the end of 1992 nearly one-third of the loan portfolios of the state-banks were non-performing. The report went on to note that there was an unusual concentration in the state banks loan portfolio with just 35 companies accounting for a large share of all loans and that 26 of the loans to these same companies were in arrears. Not surprisingly all of these 26 companies were politically well connected, with Presidential relatives heading three.

When the economic team realized the extent to which prudential regulations were being violated and the degree to which the State Banks were engaged in reckless lending, they imposed a number of regulations, including further restrictions on the issuance of liquidity credits. These measures served to sharply contract the money supply, forcing the state banks to curtail their lending. While these steps did bring about some short-term improvements they of course did little or nothing to address the underlying weaknesses in the banking system. Moreover a series of new administrative regulations were also announced. Domestic banks were required to earmark $20 \%$ of their loan portfolios for

\footnotetext{
${ }^{44}$ Ibid, p. 324.

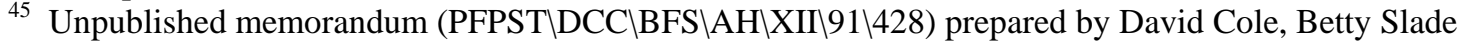
and Alison Harwood. (December 13, 1991)

${ }^{46}$ Op. cit.
} 
small business lending and foreign and joint venture banks had to allocate $50 \%$ of their credit to export oriented borrowers, steps that reflected the continued desire on the part of some government officials to revert to a more controlled and directed monetary policy framework. The economic team continued to spend time and effort on formulating the principles and the drafting of three financial laws - the Banking Law, the Insurance Law, and the Pension Fund Law - but serious differences emerged between the Ministry of Finance and Bank Indonesia over these laws. As a result even after a new banking law was passed in 1992, these differences forced the economic technocrats to set aside efforts to enact a central banking law.

In financial sector reforms, as in other reform areas, there was an increasing resistance to extending the reforms and ensuring that they were effectively and consistently implemented. Even as the economic team warned of the need for further strengthening prudential regulations and of the need to improve bank supervision, members of the Presidential family, well connected business men, and supporters of a more interventionist set of development policies, led by Minister Habibie, pushed for a more expansive credit policy that would support a more capital intensive investment program. Once again, at the very moment that the financial reforms had earned Indonesia a modicum of respect as a well managed economy, allowing domestic companies to access international capital markets, the economic team lost strength as power shifted to those whose inclination was for a more interventionist policy framework.

\section{The Benefits of Reform: Perception and Reality.}

The impact of these reforms can be measured at a number of levels. Appendix Table A-1 shows a traditional yardstick of economic performance: GDP growth and changes in its structure. Over the period 1985 - 1995, Indonesia's gross domestic product, at constant prices, grew at an annual average rate of nearly $8.0 \%$, so that per capita incomes rose from US\$533 in 1985 to US\$955 in $1995 .^{48}$ As one would expect the growth process transformed the structure of the economy. In 1985, Indonesia was still primarily an agricultural economy, with the agriculture sector contributing about one-quarter of GDP. A decade later the share of agriculture in GDP had fallen to about $16 \%$ and the country

${ }^{47}$ Financial Times, July 13, 1993. 
transformed itself from a major rice importer to a country largely self-sufficient in rice. The impact of the economic reforms introduced beginning in 1985, also raised measured total factor productivity. Collins and Bosworth estimated that total factor productivity growth in Indonesia for the period 1973 - 1984 contributed about $12 \%$ to the growth in output per worker, while physical capital contributed some $77 \% .^{49}$ But during the reform period, 1984 to 1994, Collins and Bosworth estimate that the contribution of total factor productivity nearly doubled, rising to over $24 \%$ while the contribution of physical capital to the output per worker fell to $62 \%$. These developments impressed foreign analysts and observers, deservedly so, who gave Indonesia well-deserved kudos for its economic management. These developments led to a rise in Indonesia's long-term foreign currency debt rating which had been set at BBB- on December 7, 1992 but which was raised to BBB on March 18, 1995. ${ }^{50}$ While the weaknesses in the banking system, in tax collection efforts, and in numerous other areas, as well as the shift of power away from the economic technocrats to policy makers more willing to give emphasis to government led industrial development, were well known their potential impact on Indonesia's future development were not yet visible and thus to easily discounted.

The sharp decline in poverty and the increase in rural incomes was partly the result of the growth process but also owed much to the adoption of development policies with a strong rural bias. These policies helped ensure that the considerable resources extracted from the natural resource sector were devoted to improving the rural physical infrastructure so that rural production centers were effectively linked to the growing urban markets. And as the economy shed its import substitution bias these same rural areas had increased access to world markets and to the domestic factories that were linked to them. ${ }^{51}$ In this

\footnotetext{
48 See Appendix Table A-1. Derived from GDP/capita calculated at constant 1993 prices and converted at a constant $1993 \mathrm{Rp} / \mathrm{US} \$$ exchange rate.

49 Susan Collins and Barry Bosworth, "Economic Growth in East Asia: Accumulation versus Assimilation."” Brookings Papers on Economic Activity, 2 (1996), pp. 135- 203. The remaining contribution was education per worker.

50 See www.standardandpoors.com/ratings.

51 Easier transport also connected what had been largely rural pools of underemployed labor with the new wage-labor opportunities in the cities. Indeed the close links between the rural and urban labor markets is an unusual aspect of Indonesia's development. In times of economic stress, such as the period following the financial crisis of 1997, newly unemployed rural workers return to the rural areas and are re-absorbed in rural agricultural activities.
} 
regard Indonesia's development effort certainly differed from many other such efforts that tended to neglect the rural/agricultural sector in favor the urban/industrial sector.

Rural economic growth was further strengthened by subsidies for major agricultural inputs, especially fertilizer and pesticides, and by government efforts to maintain a stable price environment for a number of important agricultural commodities, including rice. The government considered rice self-sufficiency a major policy objective. While typically food self-sufficiency is political goal the economic team correctly argued that relying on the world market for domestic supplies was a risky proposition. It put forward the notion that maximizing rice production, even in excess of efficient levels, was not without economic merit given a thin world market and a large, poor population that was heavily dependent on rice as the primary source of calories. In his analysis of food price policy, Timmer, a long-time consultant to on food policy issues in Indonesia, notes that "[i]n rice-based economies, rice price policy can affect economic growth, income distribution and political stability - three important factors in any policy-maker's objective function." 52 The economic policy team agreed and a national logistic agency, BULOG, was created to oversee the implementation of the national rice policy. The efforts to stimulate rice production and maintain a reasonable degree of rice price stability were, according to many observers, achieved at relatively modest cost during the 1980s when BULOG relied essentially market-oriented measures to achieve its goals.

Over time BULOG's role became more politicized and its function less economic in focus. The agency expanded its role beyond rice to include a number of other important food crops in which it played a leading price-setting role, often to the benefit of politically powerful parties. To promote further expansion of rice production it continued to subsidize major input, especially fertilizer, long after farmers had learned to use modern inputs efficiently. This resulted in an over use fertilizers and water, leading to sharply diminishing returns as well as environmental problems. Although initially the domestic procurement price for rice was set close to the world price, in later years, as the ruling party GOLKAR felt a need to shore up its rural political base, the rice price was set at levels that reflected political needs more than economic benefits. Between 1994 and

52 C. Peter Timmer. "Food Price Policy, the Rationale for Government Intervention," Food Policy, Vol. 14 (1) 1989 , p. 24. 
1997 the rice price was raised by more than $10 \%$ each year, a rate well above the domestic inflation rate, so that by 1997 Indonesia's rice price was some 40\% above international prices. Not this led to the accumulation of approximately one million metric tons of rice, a stock pile well above the level judged necessary to ensure rice availability, and provided an opportunity for illegal rice imports from Thailand and Malaysia. While the initial rice policy had played a major role in improving rural incomes, and reducing rural poverty, the high prices now set by BULOG had a vastly different welfare impact. In effect this policy transferred substantial incomes from rural rice consumers and lowincome urban households to net rice producers, that is from the rural and urban poor to the rural non-poor. By the time the financial crisis hit in mid-1997, the original well designed and effectively implemented rice policy had become severely distorted, BULOG had expanded its role well beyond rice and the agency had become mired in corruption.

The various reform measures, affecting trade and fiscal policies, resulted in a rapid growth in the industrial sector, which increased contribution to GDP from about $15 \%$ in 1985 to over $20 \%$ a decade later. Although much of the growth occurred in sectors engaged in the production of manufactured exports, many sectors that met the demands of the domestic consumers also expanded. As a result of the growth of the manufacturing sector, manufacturing employment rose from 5.8 million persons in 1985 to 10.8 million in 1996, an average annual increase of nearly 6\%. Although the minimum wage, admittedly half-heartedly enforced, rose during this same period, the increase in labor cost was partly offset by an even stronger rise in labor productivity, which rose by more than 5\% per annum between 1985 and $1996 .{ }^{53}$ With the number of new manufacturing sector jobs created exceeding the number of new entrants to the labor force, the large pool of under-employed was reduced.

Political development theory sometimes argues that as growth accelerates, skeptics of market based policies would see these benefits and become if not outright supporters of such policies at least less critical of such efforts. While the growing middle-class did probably realized that economic reforms had delivered tremendous benefits, a large and

53 L. Peter Rosner, "Comparison of DEPNAKER and BPS Manufacturing Productivity Data.." Unpublished memorandum; dated March 24, 1997, Jakarta, Indonesia. 
often vocal section of society, including many in the universities, continued to question whether development benefited only a few well-connected persons rather improve welfare more widely. Although data on poverty, income distribution and welfare in general often paint conflicting outcomes, the bulk of such data suggest that Indonesia's economic growth provided for considerable improvements in the economic welfare of a broad swath of the population.

First consider the poverty data. Although there are well known methodological shortcomings in the poverty estimates derived from the SUSENAS (National Economic and Social Development Survey) data, the results brought together in Table 3 have the advantage of using a consistent definition and estimation technique throughout the period covered. That is one reason why this series remains one of the best indicators of longterm changes Indonesia's poverty incidence. ${ }^{54}$ In 1976, when the first poverty estimates were made, some 54.2 million Indonesians, or roughly $40 \%$ of population, lived in poverty, but over the next twenty years the number and the proportion of poor declined rapidly, in both the urban and rural areas. By 1996 the total poverty rate had declined to $11.3 \%$, with most of the decline occurring among the rural population where the number of poor fell from 44.2 million in 1976 to 15.3 million in 1996 . While much of Indonesia's development was urban based, rural development was not neglected.

${ }^{54}$ For a discussion of the theoretical issues underlying the Indonesian poverty estimates see Franck S. Wiebe, Measuring Poverty in Indonesia: Identifying the Poor under Heterogeneous Conditions. Doctoral dissertation submitted to Stanford University, 1994. 
Table 3

Poverty Incidence and Number of Poor

(by Rural and Urban areas)

\begin{tabular}{|c|c|c|c|c|c|c|}
\hline \multirow[b]{2}{*}{ Year } & \multicolumn{3}{|c|}{$\frac{\text { Poverty Incidence }}{\text { (Headcount index) }}$} & \multicolumn{3}{|c|}{$\underline{\text { Numbers of Poor }}$} \\
\hline & Urban & $\frac{\text { Rural }}{\text { (Percent) }}$ & Total & $\underline{\text { Urban }}$ & $\stackrel{\text { Rural }}{\text { (Millions) }}$ & Total \\
\hline 1976 & 38.8 & 40.4 & 40.1 & 10.0 & 44.2 & 54.2 \\
\hline 1978 & 30.8 & 33.4 & 33.3 & 8.3 & 38.9 & 47.2 \\
\hline 1980 & 29.0 & 28.4 & 28.6 & 9.5 & 32.8 & 42.3 \\
\hline 1981 & 28.1 & 26.5 & 26.9 & 9.3 & 31.3 & 40.6 \\
\hline 1984 & 23.1 & 21.2 & 21.6 & 9.3 & 25.7 & 35.0 \\
\hline 1987 & 20.1 & 16.1 & 17.4 & 9.7 & 20.3 & 30.0 \\
\hline 1990 & 16.8 & 14.3 & 15.1 & 9.4 & 17.8 & 27.2 \\
\hline 1993 & 13.5 & 13.8 & 13.7 & 8.7 & 17.2 & 25.9 \\
\hline 1996 & 9.7 & 12.3 & 11.3 & 7.2 & 15.3 & 22.5 \\
\hline
\end{tabular}

Second, a wide-range of social indicators provides further evidence of a fairly widespread development process. Life expectancy at birth rose from 47 years in 1970 to 65 years in 1997, while infant mortality declined from 118/1,000 live births to 44/1,000 live births over the same period. Eighty percent of the population had access to health care, albeit at relatively low standards, and $62 \%$ of the population had safe drinking water. The government managed a highly successful immunization campaign so that by 1997 over 90\% of children received DPT and measles immunizations while the adult literacy rate rose from 54\% in 1970 to $85 \%$ in 1997 and the gross female primary school enrollment ratio rose from $73 \%$ in 1970 to $110 \%$ in 1996 (and the net rate stood at $98.6 \%$ ). ${ }^{55}$ The percentage of urban and rural households that owned a motorcycle or television set, were served by electric power, and lived in structures with brick walls all increased. ${ }^{56}$

So why, despite these well known and often quoted statistics, did many Indonesians continue to hold to the view that the long period of economic growth had done little to help the poor or improve their welfare? Why was it a common view that the past growth

\footnotetext{
${ }^{55}$ World Bank, World Development Indicators. CD-Rom 2000.

56 L. Peter Rosner. "Indicators of Broad-based Income Growth." Unpublished memorandum, Jakarta, Indonesia (June 5, 1997).
} 
had contributed to a worsening of income distribution and had left the poor ever further behind? There are a number reasons that can help explain this paradox.

Consider first that the Indonesian poverty line is admittedly low, in fact lower than the oft-quoted World Bank poverty line of US\$1.00/day. Hence even after the substantial improvements in the income levels of the poor, this still left many households facing extremely difficult conditions. To many observers the decline in the measured number of poor did not reflect the reality on the ground, which was that widespread poverty, still characterizes much Indonesia. While it is true that a higher poverty line would show more Indonesians living in poverty, it is also true that if a higher poverty line had been adopted at the outset and applied consistently over time, the data would still show a dramatic decrease in the measured number of poor. ${ }^{57}$ A different perspective argues that poverty is not a static situation but rather one that characterizes different households at different times. In this dynamic view of poverty whether a household classified as poor or "near-poor" depends on the probability that certain factors will either push a family below the poverty line or raise it above the poverty level. Viewing poverty as a probabilistic event provides a vastly different perspective on who is poor or at high risk of becoming poor. The poor are now defined to consist not only of individuals below the poverty line but also those facing a high probability that price or income changes will push them in to, or out of, poverty.. ${ }^{58}$ Defining poverty to include those below the poverty line plus those who face a high probability of falling in to poverty obviously increases the number of poor. However the critical issue is whether past policies that seemingly raised many households out of poverty also decreased the probability that those classified as "near poor," would revert to poverty status. ${ }^{59}$ That issue is still not settled.

Another argument raised against the apparent success of Indonesia's development strategy turns the spotlight on the issue of income distribution. Some critics of the

\footnotetext{
57 Cf. Franck Wiebe, "Poverty in Indonesia: Estimates and Measurement Issues." Unpublished memorandum dated October 18, 1993, Jakarta, Indonesia.

58 Cf. Lant Pritchett, Asep Suryahadi, and Sudarmo Sumarto, "Quantifying Vulnerability to Poverty: A Proposed Measure with Application to Indonesia," SMERU Working Paper, January 2000; and Menno Pradhan, Asep Suryahadi, Sudarmo Sumarto and Lant Pritchett, "Measurement of Poverty in Indonesia: 1996, 1999 and Beyond." SMERU Working Paper, June 2000.
} 
economic reforms argued that income distribution worsened throughout the period of rapid growth. There is in fact some evidence for this. The Gini coefficient, calculated from expenditure data, show that income distribution improved with the Gini-coefficient falling from 0.35 in 1970 to 0.32 in 1990. But thereafter the data suggest some worsening in the distribution with the Gini coefficient rising to 0.34 in 1993 and to 0.36 in 1996, a rise that occurred in both rural and urban areas although the increase in the rural Gini-coefficient was small. As always when dealing with income distribution data a strong dose of caution is called. In this case it is not clear whether the deterioration in the measured income distribution that occurred from 1993 on was a short run aberration or indeed the beginning of a more disturbing trend. On the basis of the available evidence it would be difficult to argue that Indonesia's open economy growth strategy led to a significant worsening in the distribution of income. ${ }^{60}$

Finally, there are situations where poverty levels decline, where the living standards of the poor increase, and where income distribution has not deteriorated, that the income distribution changes in such a manner at to give rise to a belief that social welfare has worsened. Ravallion and Chen point out that "[i]nequality may well decrease with reform ... and yet society may become more polarized, with heightened social tensions arising from the polarization effects of diverse impacts among middle-income groups, whereby some become poorer, while others prosper." ${ }^{61}$ It is possible for measured poverty to decline and for income inequality, as measured by the familiar Ginicoefficient, to improve but for polarization to increase as the income distribution becomes more bi-modal. It is this polarization that appears to some to reflect a worsening of income distribution or a lack of improvement in the welfare of the poorer segments of society. Ravallion and Chen suggest that claims about rising income inequality may be based on a perceived increased polarization of the income distribution rather than on an actual deterioration in the distribution. This effect may well have

\footnotetext{
59 There are no time series data as yet that use the new probabilistic analysis of poverty so that it is not possible to see how past policies changed the probability of moving in to and out of poverty.

${ }^{60}$ Perhaps less relevant Indonesia's income distribution compares favorably to that found in neighboring countries. Over the period 1993-98, the Gini index was 36.5 for Indonesia, 41.3 for Thailand, 46.2 for the Philippines and 48.5 for Malaysia. World Bank. World Development Indicators 2000.

${ }_{61}$ Martin Ravallion and Shaohua Chen. "What Can New Survey Data Tell Us about Recent Changes in Distribution and Poverty?" The World Bank Economic Review. Vol. II, No. 2 (1997), p. 367.
} 
contributed to the persistent feeling in Indonesia that the result of many of the economic reforms was not an improvement in general welfare but only in the welfare of the rich.

The Denouement.

As suggested there was a weakening in the strong reform focus that had helped Indonesia grow rapidly any economy, it was not until the mid-1990s that a number of problems emerged that provided stark evidence that the ability of the economic team to manage serious macroeconomic problems had been substantially eroded. There was growing evidence that the economy was overheating in early the 1990s and the rapid growth in imports, combined with a slowdown in exports, suggested that the real exchange rate had appreciated. Although the government took some steps to reduce domestic demand, export growth remained weak and Indonesia's debt, especially short-term private debt, continued to rise.

The export slowdown, noted earlier, was partly due to a rapid rise in the minimum wage that raised production costs. When combined with the failure to keep the real exchange rate roughly constant, this eroded the competitiveness the competitiveness of Indonesia's labor-intensive export activities.. While the minimum wage laws generally had been widely ignored in the 1990s labor policy became a more serious issue partly because of growing labor unrest and partly because of the growing international charge that Indonesia's labor intensive exports were produced in "sweat shops." Those who argued that the enforcement of the minimum wage would help reduce poverty now also argued that raising the minimum wage was necessary to avoid retaliatory trade restrictions on labor-intensive exports. These arguments found favor with President Soeharto who urged that raising the minimum wage receive high priority in efforts to raise labor incomes and counter labor unrest. ${ }^{62}$ Whether this led to a more serious effort at enforcing the minimum wage is doubtful but it may well have resulted in a stricter enforcement for of the minimum wage law in foreign firms, especially those located in the various free-trade zones where they were easily subject to government scrutiny. Thus while the overall impact of the higher minimum wage might not have been particularly severe in general it may have had a disproportionate impact precisely on those firms that had been the engine

62 Kompas, October 14, 1992 and June 3, 1993 as reported in Chris Manning, "Emerging Asia: The Indonesian Case," p. 13. 
of the export-led growth phenomenon. A 1994 review of macroeconomic developments noted that the exports of textile fabrics and garments declined, although there was a modest recovery in the following year, while the growth in shoe exports, which had decelerated every year since 1992, fell to an anemic rate of about $9 \%$ in 1995 . The labor intensive "textile, clothing, footwear" (TCF) group as a whole experienced negative growth in 1994 and very slow growth thereafter so that for all of 1996 non-oil exports grew by only about $9 \%$, the lowest rate of growth for such exports since 1990 . The combination of slow manufactured export growth together with a continued strong demand for imports led to a current account deficit of 3.5\% of GDP in 1996/97.

Equally disturbing was the decline in foreign private investment approvals in the first quarter of 1997 and the decline in international oil prices, all of which caused further concern about the widening current account deficit. And a report prepared in the Ministry of Finance noted that to"...the continued poor growth in non-oil exports one must now add the likely slowdown in the value of oil and gas exports in line with the decline in world energy prices. Thus even though import growth is moderating, export growth does not seem sufficiently robust to suggest that the current account deficit will decline over the near-term."63

A number of steps were taken to deal with the possible overheating of the economy and to improve the general macroeconomic climate. Bank Indonesia widened the intervention bands to around $3 \%$, and then to $5 \%$, of the mid-rate, hoping to introduce more flexibility into the foreign exchange market and warn offshore borrowers that there were considerable foreign exchange risks that had to be covered. But as happened a number of times before, the widening of the bands immediately saw the exchange rate rise to appreciation edge of the band, suggesting that the foreign exchange markets were not unduly concerned about any immediate depreciation. The government attempted to force the state-owned enterprises to scale back on their import levels and imposed ceilings on government foreign borrowing. It also took other measures to ensure greater access to foreign exchange reserves should the need arise. ${ }^{64}$

\footnotetext{
63 Ministry of Finance. Quarterly Economic Report. May 13, 1997.

64 Chris Manning, op cit., p. 9.
} 
The slowdown in exports and the rising current account deficit played out against Indonesia's relatively heavy debt burden. In 1993, the World Bank ranked Indonesia as the fourth largest developing country debtor. ${ }^{65}$ The stock of debt, shown in Table 4, increased at over the following two years but with substantial increases in private nonguaranteed and short-term debt. ${ }^{66}$ The rise in private debt reflected the increased capacity of Indonesian corporations to borrow overseas as well as their desire to use foreign financing since the interest rate charged on such funds often were substantially below domestic interest rates, even after due allowances is made for expected exchange rate movements. ${ }^{67}$ As a result of these trends, the ratio of foreign exchange reserves to shortterm debt fell from $67 \%$ in 1990 to less than $60 \%$ by 1992 and to $53 \%$ in 1995, despite an increase in foreign exchange reserves. While data on short-term debt is now readily available, such was not the case in the mid-1990s in part because the economic team, suspicious that bank Indonesia would use the pretext of collecting such data as a means of controlling capital flows, rejected suggestions that some effort be made to record short-term foreign borrowing.

The economic team was aware that a number of Soeharto cronies, often joined by members of the President's family, used the state banks, always subject to political pressure, to join with foreign banks to fund a range of increasingly large dubious investment projects. Unfortunately foreign lenders assumed that the presence of the state banks implied a measure of sovereign guarantee. In October 1991, in an effort to control offshore borrowing, a cabinet level committee was formed to vet all large projects that had

65 Steven Radelet. "Indonesian Foreign Debt: Heading for a Crisis or Financing Sustainable Growth?" Bulletin of Indonesian Economic Studies, Vol. 31, No. 3 (December 1995) pp. 39 - 72 . Despite the somewhat ominous title Radelet concluded that "Indonesia does not appear to be headed toward a debt crisis, either now or in the immediate future." [p. 67]

66 It is not clear whether the government had ready access to data on private debt exposure and its term structure. Data on offshore borrowing by private entities were not automatically recorded by Bank Indonesia or any other government agency. The economic team, suspicious that Bank Indonesia would use the data collecting function as a means of controlling capital flows, and the fear by the private sector that providing information to Bank Indonesia would result in rent-extraction, defeated suggestions for such data gathering efforts.

67 Many corporations betting that the exchange rate would remain relatively stable in the near term opted to avoided the cost of hedging, further reducing the cost of offshore borrowing. 


\begin{tabular}{|c|c|c|c|c|c|c|c|c|}
\hline \multicolumn{9}{|l|}{ Table 4} \\
\hline $\begin{array}{l}\text { Indonesia's Foreign Debt: } 1990 \text { - } 1997 \\
\text { (End of period; \$ million) }\end{array}$ & 1990 & 1991 & 1992 & 1993 & 1994 & 1995 & 1996 & 1997 \\
\hline 1. Total external debt & $69,871.5$ & $79,547.7$ & $88,002.2$ & $89,171.9$ & $107,823.9$ & $124,398.3$ & $128,940.6$ & $136,173.1$ \\
\hline $\begin{array}{l}\text { 2. Long-term debt } \\
\text { of which: }\end{array}$ & $58,242.3$ & $65,067.4$ & $69,945.1$ & $71,184.9$ & $88,366.9$ & $98,432.0$ & $96,710.2$ & $100,337.8$ \\
\hline 2a Public/publicly guaranteed debt & $47,981.8$ & $51,891.4$ & $53,664.1$ & $57,155.9$ & $63,926.0$ & $65,308.8$ & $60,015.8$ & $55,869.0$ \\
\hline $2 b$ Private non-guaranteed debt & $10,260.5$ & $13,176.0$ & $16,281.0$ & $14,029.0$ & $24,440.9$ & $33,123.2$ & $36,694.3$ & $44,468.8$ \\
\hline 3. Short-term debt & $11,135.3$ & $14,314.8$ & $18,057.1$ & $17,987.0$ & $19,457.0$ & $25,966.3$ & $32,230.4$ & $32,865.0$ \\
\hline 4. Use of IMF credits & 493.9 & 165.5 & 0.0 & 0.0 & 0.0 & 0.0 & 0.0 & $2,970.3$ \\
\hline 5. Foreign exchange reserves & $7,549.1$ & $9,257.9$ & $10,448.6$ & $11,262.7$ & $12,132.7$ & $13,708.2$ & $18,251.0$ & $16,586.9$ \\
\hline \multicolumn{9}{|l|}{ Key indicators } \\
\hline $\begin{array}{l}\text { (a) Total debt/GDP (\%) } \\
\text { (b) Private non-guaranteed }\end{array}$ & 63.98 & 64.90 & 66.20 & 58.67 & 63.32 & 64.63 & 58.27 & 65.02 \\
\hline $\begin{array}{l}\text { debt/total debt (\%) } \\
\text { (c) Total debt-to-exports of goods }\end{array}$ & 14.68 & 16.56 & 18.50 & 15.73 & 22.67 & 26.63 & 28.46 & 32.66 \\
\hline $\begin{array}{l}\text { and services (\%) } \\
\text { (d) Debt services-to-exports of goods }\end{array}$ & 233.59 & 234.85 & 219.37 & 210.94 & 231.81 & 233.89 & 219.60 & 226.56 \\
\hline and services (\%) & 33.25 & 33.88 & 31.05 & 33.33 & 30.67 & 30.87 & 36.68 & 32.84 \\
\hline (e) Reserves-to short-term debt (\%) & 67.0 & 64.7 & 57.9 & 62.6 & 62.4 & 52.8 & 56.6 & 50.5 \\
\hline $\begin{array}{l}\text { (f) Foreign exchange reserves } \\
\text { (month of imports) }\end{array}$ & 3.3 & 3.5 & 3.6 & 3.5 & 3.3 & 3.0 & 3.7 & 3.2 \\
\hline
\end{tabular}

Source: Lines 1, 2, and 3 from World Bank, World Development Indicators, 2000.

GDP, reserves, and trade data from IMF, International Financial Statistics, 2001. 
ment connection. ${ }^{68}$ But many of these large projects, including the already mentioned Chandra Asri Petrochemical plant, quickly reconstituted themselves as fully foreign owned projects, thus avoiding scrutiny by the oversight committee. In other instances the decision of the committee was simply overruled. ${ }^{69}$ On balance while the committee was able to slow down the rush to seek offshore financing for large uneconomic projects, it was never able to effectively control it.

Despite growing concerns that emerged in the early 1990s about Indonesia's economic management there were few immediate signs to suggest an immediate crisis. As Kenward notes "the broadest macroeconomic indicators were of little help in foreshadowing Indonesia's ... financial instability."70 What was not recognized was that in an open economy whose financial markets have been deregulated but are not yet well supervised, significant policy reversals are likely to have a large impact on economic stability. This arises from the greater role of domestic money and equity markets in determining investment flows, especially foreign invest flows. Viewed in this light the loss of prestige and influence of the economic team and the shift of political and economic power to the "technologists" and nationalists should have been a greater cause for concern. As the power of the economic team declined the President's family and the economic cronies aligned themselves with these new economic managers in what often proved to be poorly conceived economic programs. Moreover, these political realignments were played out against the background of an aging President whose failing health suggested that a transfer of power was not far off but who gave no sign that he had laid the grounds for a smooth transfer of authority. This raised the question of whether the reforms would in fact be carried to their natural conclusion, leaving investors to wonder whether, when some still unforeseen difficulty arose, it would be quickly and decisively dealt with.

When the Asian crisis reached Indonesia, foreign investors suddenly realized that the slowdown in the pace of economic liberalization, the continued lack of transparency in decision-making, and the interventionist policies in favor of well-connected groups,

\footnotetext{
${ }^{68}$ Presumably any involvement of state bank was included in the definition of government involvement although the definition was never made entirely clear. In any event this effort came to naught.

${ }^{69}$ See Adam Schwarz, op cit. pp. 152 - 153.

${ }^{70}$ Lloyd R. Kenward, op cit., p. 90.
} 
would make it difficult for the government to mount an effect stabilization policy. And indeed that is what happened. 
Appendix Table A-1

Gross Domestic Product by Industrial Origin

(Rp. Billion; at constant 1993 market prices)

1. Agriculture, livestock, forestry, fishing

2. Mining and quarrying

(a) Oil and natural gas

(b) Other mining and quarrying

3. Industry

(a) Refining oil and gas

(b) Non-oil and gas manufacturing

4. Electricity, gas and water

5. Construction

6. Trade, hotels and restaurants

7. Transport and communications

8. Banking and financial services

9. Ownership of dwellings ${ }^{(a)}$

10. Services

(a) General government

(b) Private services

Gross Domestic Product

Rate of growth (\% per annum)

Population (millions)

Exchange rate (end-of-period; Rp/US\$)

GDP/capita (constant 1993 prices and

\begin{tabular}{|c|c|c|c|c|c|c|c|c|c|c|}
\hline 1985 & 1986 & 1987 & 1988 & 1989 & 1990 & 1991 & 1992 & 1993 & 1994 & 1995 \\
\hline$\overline{43,700}$ & $4 \overline{5,443}$ & $4 \overline{46,932}$ & $\overline{49,073}$ & $\overline{51,476}$ & $\overline{53,056}$ & $\overline{54,583}$ & $\overline{58,002}$ & $\overline{58,963}$ & $\overline{59,291}$ & $\overline{61,885}$ \\
\hline 21,294 & 22,378 & 23,264 & 23,241 & 24,832 & 26,628 & 29,969 & 30,461 & 31,497 & 33,262 & 35,502 \\
\hline 19,298 & 20,224 & 20,330 & 19,837 & 20,823 & 21,799 & 23,923 & 23,097 & 23,121 & 23,720 & 23,720 \\
\hline 1,996 & 2,154 & 2,934 & 3,405 & 4,010 & 4,829 & 6,046 & 7,364 & 8,377 & 9,542 & 11,782 \\
\hline 32,435 & 35,812 & 39,399 & 43,516 & 48,426 & 54,212 & 59,941 & 66,042 & 73,556 & 82,649 & 91,637 \\
\hline 5,937 & 6,567 & 6,951 & 7,495 & 7,897 & 8,750 & 9,272 & 9,710 & 9,794 & 10,269 & 9,782 \\
\hline 26,498 & 29,244 & 32,448 & 36,022 & 40,529 & 45,462 & 50,669 & 56,332 & 63,763 & 72,380 & 81,855 \\
\hline 1,161 & 1,379 & 1,596 & 1,850 & 2,100 & 2,508 & 2,720 & 2,961 & 3,290 & 3,703 & 4,292 \\
\hline 9,674 & 9,918 & 10,488 & 11,499 & 13,022 & 15,226 & 17,489 & 19,664 & 22,513 & 25,858 & 29,198 \\
\hline 25,573 & 28,139 & 30,837 & 33,963 & 37,714 & 41,725 & 46,669 & 50,344 & 55,298 & 59,504 & 64,231 \\
\hline 12,368 & 13,209 & 14,134 & 15,272 & 16,917 & 18,474 & 20,040 & 21,618 & 23,249 & 25,189 & 27,329 \\
\hline 13,166 & 14,706 & 15,290 & 15,574 & 18,317 & 10,102 & 11,425 & 12,735 & 14,005 & 15,945 & 18,109 \\
\hline n.a. & n.a. & n.a. & n.a. & n.a. & 8,210 & 9,372 & 9,533 & 9,695 & 10,087 & 10,643 \\
\hline 21,807 & 23,217 & 25,022 & 27,419 & 28,717 & 33,123 & 34,560 & 36,115 & 37,709 & 39,155 & 40,967 \\
\hline n.a. & n.a. & n.a. & 14,200 & 15,033 & 20,738 & 21,380 & 22,012 & 22,458 & 22,752 & 23,046 \\
\hline n.a. & n.a. & n.a. & 13,219 & 13,684 & 12,385 & 13,180 & 14,103 & 15,251 & 16,403 & 17,921 \\
\hline 181,176 & 194,200 & 206,963 & 221,407 & 241,521 & 263,263 & 286,767 & 307,474 & 329,776 & 354,642 & 383,793 \\
\hline & 7.19 & 6.57 & 6.98 & 9.08 & 9.00 & 8.93 & 7.22 & 7.25 & 7.54 & 8.22 \\
\hline 163.0 & 166.2 & 169.0 & 172.0 & 175.0 & 178.2 & 181.4 & 184.6 & 187.7 & 190.8 & 193.4 \\
\hline 110.58 & $1,282.56$ & $1,643.85$ & $1,685.70$ & ,770.06 & $1,842.82$ & $1,950.32$ &, 029.92 & $2,087.10$ & $2,160.75$ & $2,248.61$ \\
\hline 533 & 560 & 587 & 617 & 661 & 708 & 757 & 798 & 842 & 891 & 951 \\
\hline
\end{tabular}
exchange rate

Notes: ${ }^{(a)}$ Rental services included in "Banking and financial services" prior to 1990 and subsequently included in "Ownership of dwellings."

Source: Lines 1 - 10: Biro Pusat Statistik Indonesia, Jakarta, Indonesia. (Various publications.)

Line Population: World Bank. World Development Indicators. CD-Rom, 2000.

Line exchange rate: International Monetary Fund. International Financial Statistics, series rf, annual averages. 